\title{
Benign Iris Neoplasm
}

National Cancer Institute

\section{Source}

National Cancer Institute. Benign Iris Neoplasm. NCI Thesaurus. Code C4555.

A non-metastasizing neoplasm that arises from the iris. 